Published in "Global and Planetary Change 60(3-4): 222-234, 2007"

which should be cited to refer to this work.

\title{
Unraveling the patterns of late Holocene debris-flow activity on a cone in the Swiss Alps: Chronology, environment and implications for the future
}

\author{
Markus Stoffel $^{\mathrm{a}, \mathrm{b}, *}$, Delphine Conus ${ }^{\mathrm{a}}$, Michael A. Grichting ${ }^{\mathrm{a}, \mathrm{c}}$, \\ Igor Lièvre $^{\mathrm{a}}$, Gilles Maître ${ }^{\mathrm{a}}$ \\ ${ }^{a}$ Dendrolab.ch, Laboratory of Dendrogeomorphology, Department of Geosciences, University of Fribourg, 1700 Fribourg, Switzerland \\ ${ }^{\mathrm{b}}$ Climate Change and Climate Impacts (C ${ }^{3}$ i), University of Geneva, 1227 Carouge-Geneva, Switzerland \\ ${ }^{c}$ Service de la Protection de l'Environnement, Section EIE et Constructions, 1950 Sion, Switzerland
}

\begin{abstract}
Debris-flow activity on the forested cone of the Ritigraben torrent (Valais, Swiss Alps) was assessed from growth disturbances in century-old trees, providing an unusually complete record of past events and deposition of material. The study of 2246 tree-ring sequences sampled from 1102 Larix decidua Mill., Picea abies (L.) Karst. and Pinus cembra ssp. sibirica trees allowed reconstruction of 123 events since AD 1566. Geomorphic mapping permitted identification of 769 features related to past debrisflow activity on the intermediate cone. The features inventoried in the study area covering 32 ha included 291 lobes, 465 levées and 13 well-developed debris-flow channels. Based on tree-ring records of disturbed trees growing in or next to the deposits, almost $86 \%$ of the lobes identified on the present-day surface could be dated. A majority of the dated material was deposited over the last century. Signs of pre-20th century events are often recognizable in the tree-ring record of survivor trees, but the material that caused the growth anomaly in trees has been completely overridden or eroded by more recent debris-flow activity.

Tree-ring records suggest that cool summers with frequent snowfalls at higher elevations regularly prevented the release of debris flows between the 1570s and 1860s; the warming trend combined with greater precipitation totals in summer and autumn between 1864 and 1895 provided conditions that were increasingly favorable for releasing events from the source zone. Enhanced debris-flow activity continued well into the 20th century and reconstructions show a clustering of events in the period 1916-1935 when warm-wet conditions prevailed during summer in the Swiss Alps. In contrast, very low activity is observed for the last 10-yr period (1996-2005) with only one debris-flow event recorded on August 27, 2002. Since sediment availability is not a limiting factor, this temporal absence of debris-flow activity is due to an absence of triggering events, which not only shifted from June and July to August and September over the 20th century, but also seemed to be initiated primarily by persistent precipitation rather than summer thunderstorms. From the reconstructions, based on RCM simulations, there are indications that debris-flow frequencies might continue to decrease in the future, as precipitation events are projected to occur less frequently in summer but become more common in spring or autumn.
\end{abstract}

Keywords: Debris flow; tree-ring analysis; dendrogeomorphology; deposition processes; climate change; Swiss Alps

\footnotetext{
* Corresponding author. Dendrolab.ch, Laboratory of Dendrogeomorphology, Department of Geosciences, University of Fribourg, 1700 Fribourg, Switzerland. Tel.: +41 2630090 15; fax: +41263009746.

E-mail address: markus.stoffel@unifr.ch (M. Stoffel).
} 


\section{Introduction}

Debris flows represent one of the most common and widespread of all natural hazards in mountain environments, where they repeatedly cause damage to infrastructure or even loss of life on cones or at the mouth of gullies (Jakob and Hungr, 2005). With the projected greenhouse warming (Christensen and Christensen, in press), there is much debate about changes in the frequency, magnitude and seasonality of precipitation events and related flooding or mass-wasting processes (e.g., Bradzil et al., 2002; Milly et al., 2002; Christensen and Christensen, 2002; Beniston, 2006). Before establishing any cause-and-effect relationship between global warming and the incidence of geomorphic processes, the natural variability of extreme weather events must be examined as well as detailed information obtained on past process dynamics on debris-flow cones, alluvial fans or floodplains. Sletten et al. (2003) pertinently emphasize that records of past debris-flow activity may be particularly useful in the recognition of past process dynamics and precipitation events. Individual debris flows are usually released during intense rainfall events (Caine, 1980; Blikra and Nemec, 1998, 2000) and repetitive debris flows usually occur in sediment-rich catchments, as long as the triggering precipitation events are recurring (Zimmermann et al., 1997). In addition, debrisflow deposits have a high preservation potential on cones and can therefore be used for the analysis of spatial patterns of past events (Bollschweiler et al., in press).

While chronostratigraphic records on past debris-flow activity exist for several case-study areas of northern Europe or the United States (e.g., Brazier et al., 1988; Jonasson, 1993; Matthews et al., 1997; Blair, 1999), such reconstructions remain widely non-conclusive for the European Alps in general and for Switzerland in particular.

It is therefore the purpose of this paper to assess late Holocene debris-flow activity and process dynamics on

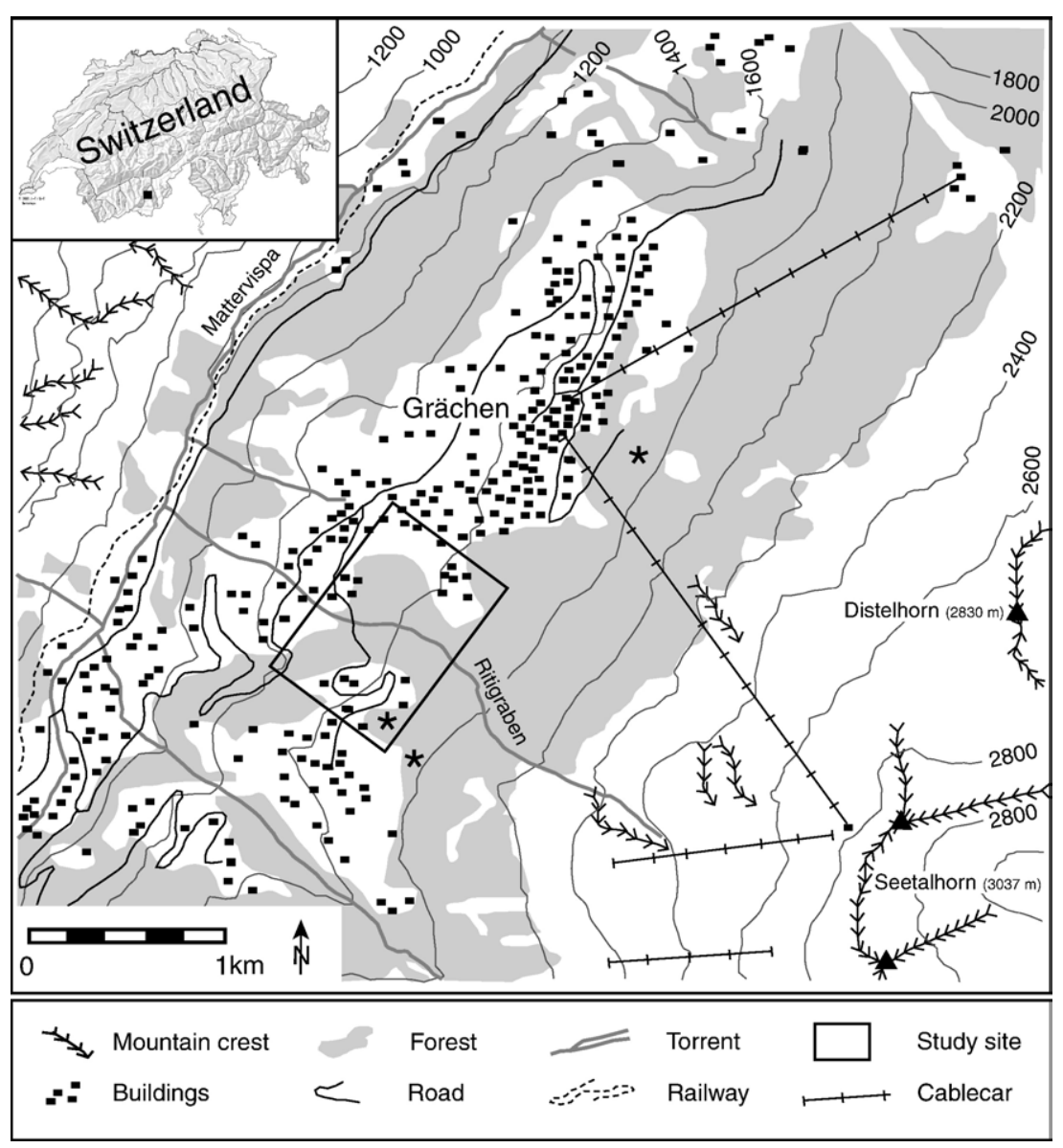

Fig. 1. The Ritigraben torrent (Valais, Swiss Alps) rises from its source at $2600 \mathrm{~m}$ asl and passes through a forested cone located on a structural terrace near the village of Grächen, before converging with the Mattervispa river $(1080 \mathrm{~m}$ asl). 
a forested cone in the Swiss Alps using dendrogeomorphological methods. Through the identification of surface deposits and analysis of 2246 tree-ring series obtained from 1102 old-growth trees disturbed by past debris flows, we (i) investigate the frequency and timing of events, (ii) date the material deposited on the present-day cone surface, and (iii) discuss potential effects of projected changes in climatic conditions upon the frequency and magnitude of events in a future greenhouse climate.

\section{Study area}

Our analysis of debris-flow dynamics and growth disturbances in century-old trees was conducted around the Ritigraben torrent (Grächen, Valais, Switzerland, $46^{\circ}$ $11^{\prime} \mathrm{N}, 7^{\circ} 49^{\prime} \mathrm{E}$ ). Figs. 1 and $2 \mathrm{~A}$ show the torrent beginning at $2600 \mathrm{~m}$ asl. In its source zone, geophysical prospecting and BTS (i.e. basal temperatures of snow; see Brenning et al., 2005) measurements indicate the existence of contemporary permafrost (Lugon and Monbaron, 1998).

On its downward course to the Mattervispa river, the torrent passes a large forested cone ( 32 ha; ca. $\left.4.3 \times 10^{6} \mathrm{~m}^{3}\right)$ on a structural terrace $(1500-1800 \mathrm{~m}$ asl), where debris-flow material affects trees within an oldgrowth stand composed of European larch (Larix decidua Mill.), Norway spruce (Picea abies (L.) Karst.) and Swiss stone pine (Pinus cembra ssp. sibirica). Fig. 2B illustrates the intermediate debris-flow cone, which is of Holocene age.

At the confluence of the Ritigraben torrent with the receiving Mattervispa River at $1080 \mathrm{~m}$ asl, depositional features are lacking and debris-flow material is immediately eroded. Debris-flow material consists of heavily disintegrated, weathered metamorphic granites of Permian age (Labhart, 2004) partly originating from the steep source zone of the Ritigraben torrent, where an active rock glacier provides material for the initiation of debris flows. Further debris is mobilized from the channel, which is continuously recharged with fallen rocks or through bank erosion. While mean rock sizes on the cone surface generally remain well below $2 \mathrm{~m}$ in diameter, there is also evidence that boulders with volumes exceeding $10 \mathrm{~m}^{3}$ have been transported by debris flows in the past.

The high elevation of the source area currently restricts debris-flow activity in the Ritigraben torrent from June to September (Stoffel et al., 2005a). Present-day debris-flow activity is initiated primarily by persistent precipitation in autumn rather than summer thunderstorms. The documentation of past events only covers the last 20 years, with the "largest event ever" recorded in 1993 having eleven erosive surges and an estimated volume of $60,000 \mathrm{~m}^{3}$ (Zimmermann et al., 1997).

Geomorphic processes other than debris flows are negligible at the study site: Snow avalanches have never been witnessed on the Ritigraben cone. Similarly, the source area and bed lithology are not suitable for the formation of floods and the torrent lays dry during most of the year. Rockfall exclusively occurs in its uppermost part, which has been disregarded for analysis.

\section{Materials and methods}

\subsection{Geomorphological mapping of debris-flow chan- nels and deposits}

Analysis of past debris-flow activity began with a detailed mapping of all features associated with past

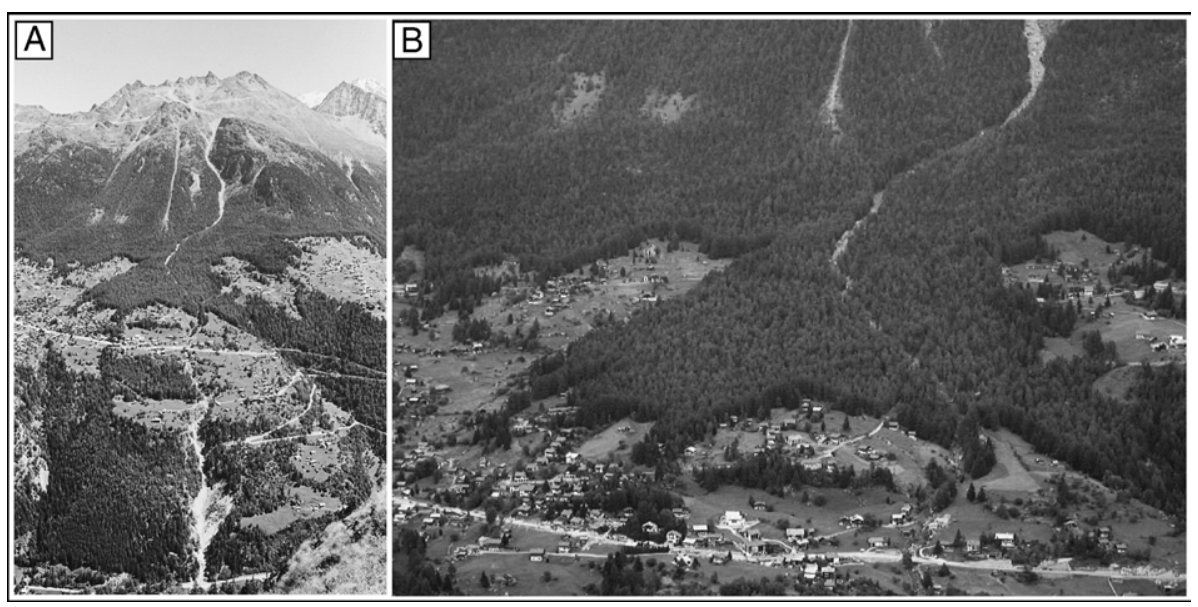

Fig. 2. (A) Photo of the Ritigraben debris-flow system from its source to the confluence (catchment area: $1.36 \mathrm{~km}^{2}$, channel lengths: $3.5 \mathrm{~km}$ ). (B) Detailed view of the intermediate debris-flow cone (32 ha) and its mixed conifer stand 
events, such as lobes, levées or abandoned flow paths on a scale of 1:1000. Features and deposits originating from other geomorphic processes or anthropogenic activity were indicated on the map as well, so as to avoid misdating of debris-flow events. Due to the presence of a relatively dense forest cover, GPS could not be used on the cone, which is why geomorphic mapping was executed with a tape, inclinometer and compass. In addition, the mean size of blocks was measured for every individual lobe and levée $(<0.5 \mathrm{~m}$, $0.5-1 \mathrm{~m}, 1-2 \mathrm{~m}$ ) and the vegetation cover present on the features was qualitatively assessed (light, medium, dense).

\subsection{Sampling design}

On the intermediate debris-flow cone covering approximately 32 ha, a majority of the century-old conifers (L. decidua Mill., P. abies (L.) Karst., P. cembra ssp. sibirica) show visible growth defects related to past debris-flow activity (i.e. tilted stems, partial burying of the trunk, destruction of root mass, erosion, scars). Based on the detailed geomorphic map and on an outer inspection of the stem surface, we preferably sampled trees obviously disturbed by past debris flows.

In this investigation, at least two cores were extracted per tree using increment borers, one in the flow direction of past debris flows and the other on the opposite side of the trunk (max. length of cores: $40 \mathrm{~cm}$ by $6 \mathrm{~mm}$ ). In order to gather the greatest amount of information on the growth disturbances (GD) caused by past events, increment cores were preferably sampled at the height of the visible damage or within the segment of the stem tilted during past events. In the case of visible scars, further increment cores were extracted from the wound and the overgrowing callus tissue.

In addition to the disturbed trees sampled on the cone, we selected undisturbed reference trees from a forest stand located southwest of the cone, indicated with asterisks in Fig. 1. For every single reference tree, two cores per tree were extracted parallel to the slope direction. In total, 1204 trees were sampled (2450 increment cores): 539 L. decidua, 429 P. abies and 134 P. cembra trees (2246 cores) from the debris-flow cone as well as 102 trees (204 cores) of the same species from undisturbed reference sites. In contrast to the disturbed trees, increment cores of the reference trees were extracted at breast height $(\approx 130 \mathrm{~cm})$.

Data recorded for each tree sampled included: (i) determination of its position within levées, flow channels or on deposits; (ii) sketches and position of visible disturbances in the tree morphology such as tilted stems, partial burying of the stem, destruction of root mass or erosion as well as scars; (iii) position of the sampled cores on the stem surface; (iv) diameter at breast height $(\mathrm{DBH})$ derived from circumference measurements; and (v) data on neighboring trees.

\subsection{Debris-flow frequency and timing of events}

Samples were analyzed and data processed following the standard procedures described in Bräker (2002). Single steps of sample analysis included surface preparation, skeleton plots as well as ring-width measurements using digital LINTAB positioning tables connected to a Leica stereomicroscope and TSAP 3.0

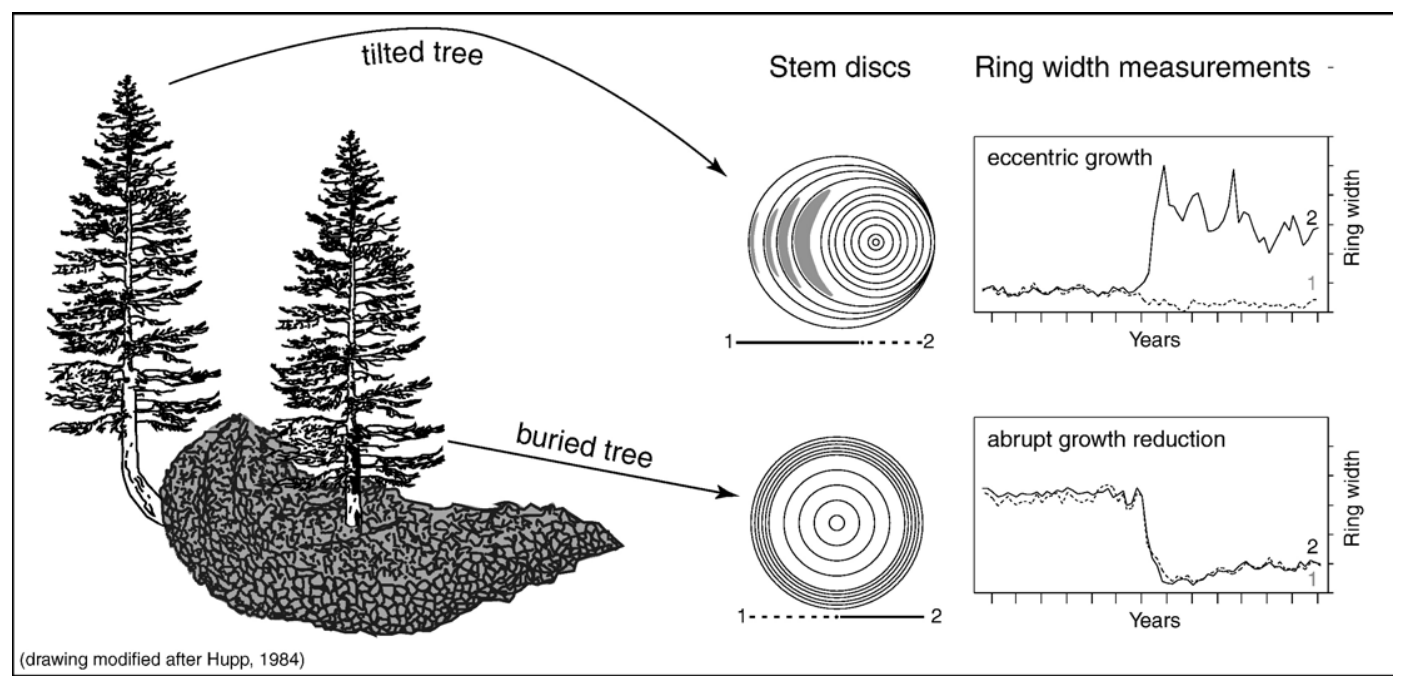

Fig. 3. Tree-ring 'signatures' used to determine the age of debris-flow deposits (drawing modified after Hupp, 1984). 
(Time Series Analysis and Presentation) software (Rinntech, 2006). Growth curves of the disturbed samples were then crossdated with the corresponding reference chronology constructed from undisturbed trees for each of the three conifer species sampled on the cone (L. decidua, P. abies, P. cembra), in order to separate insect attacks or climatically driven fluctuations in tree growth from GD caused by debris flows (Cook and Kairiukstis, 1990).

Growth curves were then used to determine the initiation of abrupt growth reduction or recovery (Schweingruber, 2001; McAuliffe et al., 2006). In the case of tilted stems, both the appearance of the cells (i.e. structure of the reaction wood cells) and the growth curve data were analyzed (e.g., Braam et al., 1987; Fantucci and Sorriso-Valvo, 1999; see Fig. 3). Finally, the cores were visually inspected so as to identify further signs of past debris-flow activity in the form of callus tissue overgrowing abrasion scars or tangential rows of traumatic resin ducts formed following cambium damage (Stoffel et al., 2005b, 2006; Perret et al., 2006; Bollschweiler et al., in press). As a rule, the first decade of juvenile growth has not been included in the analysis, as tree rings in seedlings tend to be more susceptible to snow pressure and produce more resin ducts per unit area in general.

As conifer trees react immediately to damage with the formation of callus tissue or tangential rows of traumatic resin ducts, the intra-annual position of these disturbance (i.e. early, mid and late earlywood as well as early and late latewood; for details see Stoffel et al., 2005c, 2006) was used to assess the timing of debrisflow activity in particular years. For the Valais Alps, highly-resolved data exist on the timing and different periods of radial growth of $L$. decidua and $P$. abies (Müller, 1980), rendering dating of past debris-flow events at Ritigraben possible with monthly precision (Stoffel and Beniston, 2006). The results obtained on the intra-seasonal timing of debris-flow events were then compared with precipitation records from a local meteorological station, operational since December 1863, and with archival data on flooding events in rivers of the Valais Alps (Lütschg-Lötscher, 1926; Röthlisberger, 1991).

\subsection{Dating debris-flow deposits and assessing spatial patterns of past events}

After the dating of GD on the increment cores, we assessed the age of lobes by attributing severe GD in the tree-ring series to the deposits in the field. As exemplified in Fig. 3, dating of a lobe was only possible (i) if a survivor tree was injured through the deposition of material (i.e. callus tissue or tangential row of traumatic resin ducts in the growth ring); (ii) if its stem base was buried by debris (i.e. abrupt growth reduction in ring-width series); or (iii) if it was tilted (i.e. eccentric growth rings and the presence of reaction wood on the cores; see illustration in Fig. 3).

Special attention needs to be addressed to multiple GD identified in the tree-ring series. Here, only the geomorphic features left during the most recent event could be dated. Older episodes of GD identified using dendrogeomorphological methods may have been caused either by surges that passed through without leaving material or by deposits that were later eroded or overridden by more recent debris-flow activity.

\section{Results}

\subsection{Debris-flow features and deposits}

Geomorphic mapping permitted identification of 769 features relating to past debris-flow activity on the intermediate cone of the Ritigraben torrent. The features and deposits inventoried in the study area covering 32 ha included 291 lobes, 465 levées and 13 welldeveloped debris-flow channels. Fig. 4 illustrates the features identified on the cone and provides indications of the density of the vegetation cover. Further details on the mean diameter of blocks deposited in the lobes as well as information on the vegetation cover present on the lobes are given in Table 1 . The mean block size generally remains $<1 \mathrm{~m}$ and almost half of the deposits are covered with dense vegetation. Lobes containing mostly large blocks $(1-2 \mathrm{~m})$ are sparsely vegetated, whereas deposits with finer rock fractions $(<0.5 \mathrm{~m})$ normally have a very dense vegetation cover.

The length of lateral levées varies from a few to several dozens of meters. While some of these lateral levées appear quite isolated on the actual surface of the cone others can easily be attributed to one of the twelve major channels that were in use before the erosive 1993 event and incision of the main channel. The currently abandoned flow tracks are still clearly visible over large parts of the cone, although parts of their banks have collapsed and their beds are now filled with fallen debris and vegetation.

\subsection{Age and growth disturbances in trees}

Data on the innermost rings of the $1102 \mathrm{~L}$. decidua, $P$. abies and P. cembra trees sampled on the cone varied from AD 1492 to 1962 with 53\% of the increment cores 


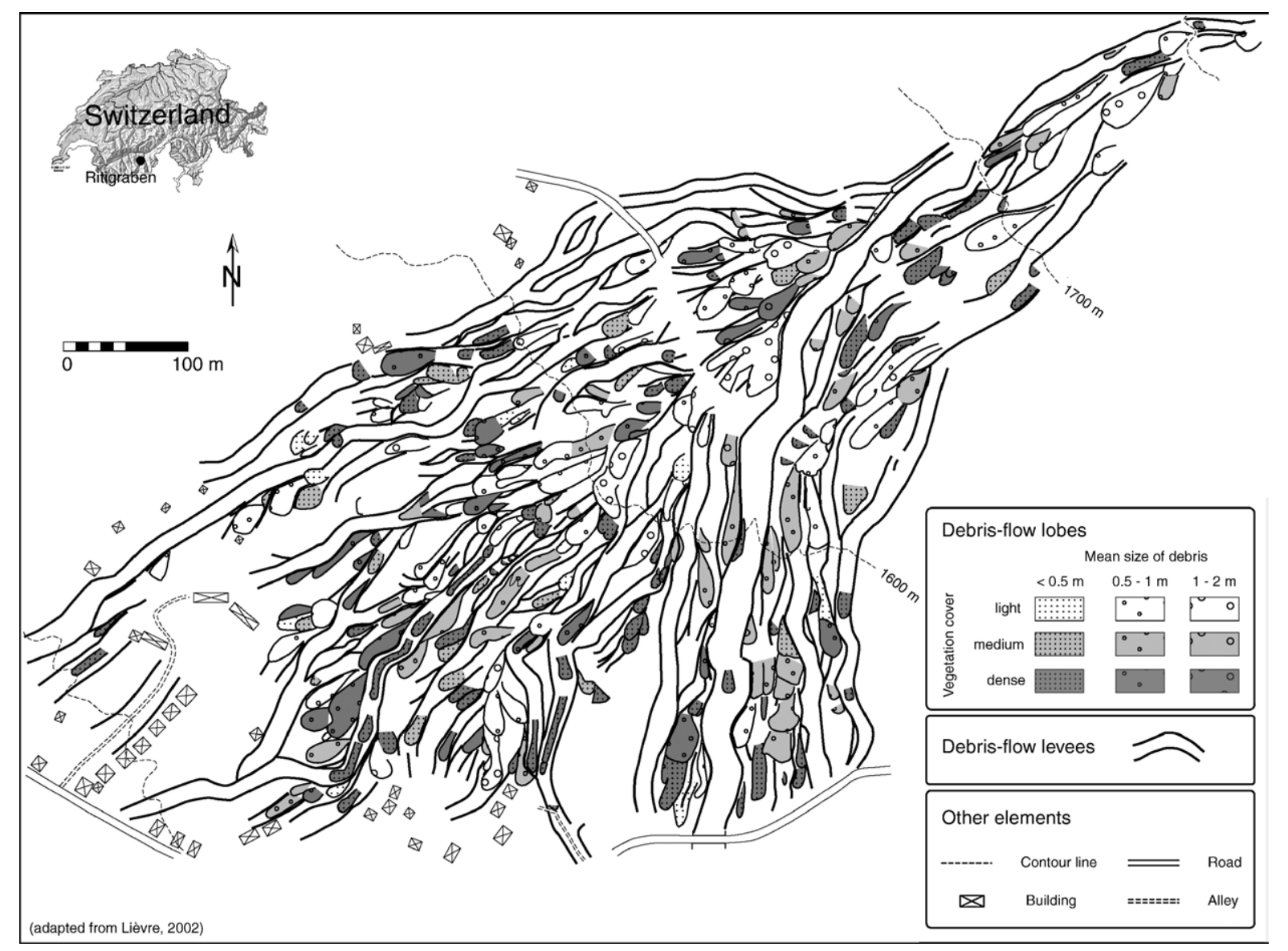

Fig. 4. Detailed geomorphological map of the intermediate debris-flow cone with lobes, levées and channels. The key indicates the density of the vegetation cover and the mean size of debris on the lobes (drawing adapted from Lièvre, 2002).

showing more than 300 tree rings at sampling height and old trees being quite evenly spread over the cone. The youngest trees, in contrast, are most commonly found near the forest fringe, where anthropogenic intervention has affected tree age and succession rates (i.e. farming activities, extraction of fire- and construction wood).

Analysis of the disturbed trees allowed reconstruction of 2263 GD caused by passing debris-flow surges or the deposition of material on the cone. Table 2 shows

Table 1

Mean block size identified in and vegetation cover on the deposits

\begin{tabular}{lllll}
\hline \multirow{2}{*}{$\begin{array}{l}\text { Vegetation } \\
\text { cover }\end{array}$} & \multicolumn{4}{l}{ Mean diameter of blocks in deposits } \\
\cline { 2 - 5 } & $<0.5 \mathrm{~m}$ & $0.5-1 \mathrm{~m}$ & $1-2 \mathrm{~m}$ & Total \\
\hline Light & 13 & 55 & 20 & $88(30 \%)$ \\
Medium & 21 & 47 & 4 & $72(25 \%)$ \\
Dense & 86 & 42 & 3 & $131(45 \%)$ \\
Total & $120(41 \%)$ & $144(50 \%)$ & $27(9 \%)$ & $291(100 \%)$ \\
\hline
\end{tabular}

that signatures of past events were mainly identified on the increment cores via tangential rows of traumatic resin ducts $(43.6 \%)$ or reaction wood $(32.1 \%)$. Abrupt growth recovery $(9.5 \%)$ or reductions $(8.6 \%)$ were only occasionally found in the tree-ring series and wounds $(5.2 \%)$ and overgrowing callus tissue $(1 \%)$ was rarely present in the cores.

Table 2

Relative number of types of growth disturbances (GD) used to infer past debris-flow activity from increment cores. TRD $=$ Tangential rows of traumatic resin ducts

\begin{tabular}{lcr}
\hline Growth anomaly & Number & \multicolumn{1}{c}{$\%$} \\
\hline TRD & 987 & 43.6 \\
Wound & 118 & 5.2 \\
Callus tissue & 22 & 1.0 \\
Reaction wood & 728 & 32.1 \\
Growth reduction & 194 & 8.6 \\
Growth release & 214 & 9.5 \\
Total & 2263 & 100.0 \\
\hline
\end{tabular}




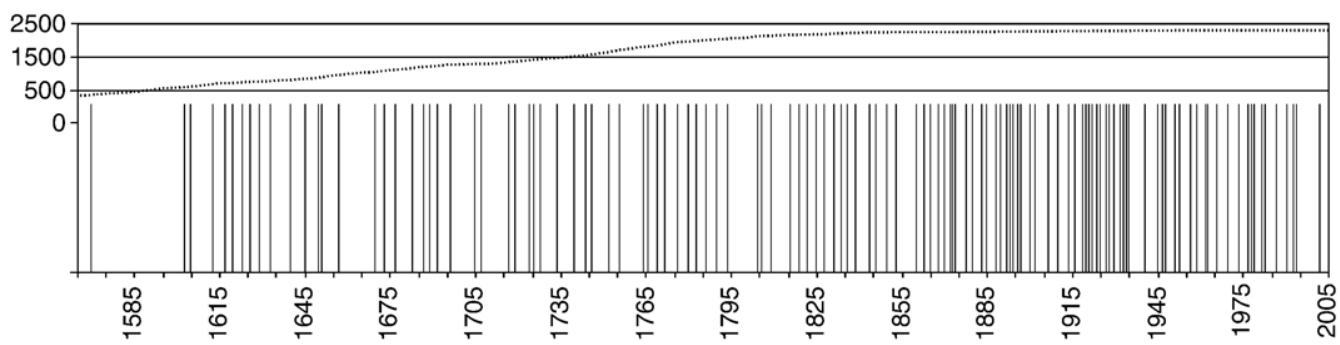

Fig. 5. Tree-ring based reconstruction of debris-flow activity at Ritigraben between AD 1566 and 2005 containing 123 events. The sample depth (dotted line) shows the number of cores available for analysis at specific years in the past.

\subsection{Debris-flow frequency and timing of events}

In total, dendrogeomorphological analysis of the increment cores allowed reconstruction of 123 debrisflow events covering the last 440 years. The reconstructed occurrence of debris flows is given in Fig. 5. From the data, it appears that periods of repeated debrisflow activity alternate with phases of little or almost no activity. Such clustering of events is especially obvious in the early $1870 \mathrm{~s}$, the $1890 \mathrm{~s}$ and between the late $1910 \mathrm{~s}$ and 1935.

The number of increment cores available for analysis at any one moment in the past is shown by a dotted line indicating 'sample depth' in Fig. 5. Based on the large sample depth used in the reconstruction and the distribution of old trees on the cone, it can be assumed that the GD caused by most events of the last 300 years have been recorded. Prior to this period, the decreasing number of trees available for analysis may influence the quality of the reconstructed frequency.

In Fig. 6, the reconstructed frequency is broken down into 10 -yr periods, with bars representing variations from the mean decadal frequency of debris flows for the period 1706-2005, when 3.26 events occurred every ten years. Results illustrate that the frequency of events generally remained well below average during most of the classical Little Ice Age (LIA, 1570-1900; Grove, 2004). Periods with increased debris-flow activity only start to emerge from the data after the last LIA glacier advance in the 1860s. This period of increased activity continued well into the early 20th century reaching a peak between 1916 and 1935. During these 20 years, the tree-ring series indicate 14 events. Results further illustrate that this major episode of activity was followed by a decrease in debris flows, with particularly low activity over the last 10-yr period (1996-2005), with only one debris-flow event recorded on August 27, 2002. The three lowest debris-flow activity periods in the last 300 years occurred in the 10 -yr periods of $1706-$ 1715 and 1796-1805 and during the most recent ten years.

The timing of past events was established by comparison of the intra-annual position of tangential rows of traumatic resin ducts in the tree rings with highly-resolved growth data of $L$. decidua and $P$. abies growing in the Valais Alps, meteorological records from the local MeteoSwiss station (1863-2005) and with archival data on river flooding in the Valais Alps. Results showing the timing of debris-flow activity, presented in Fig. 7, indicate that events generally occurred much earlier in summer

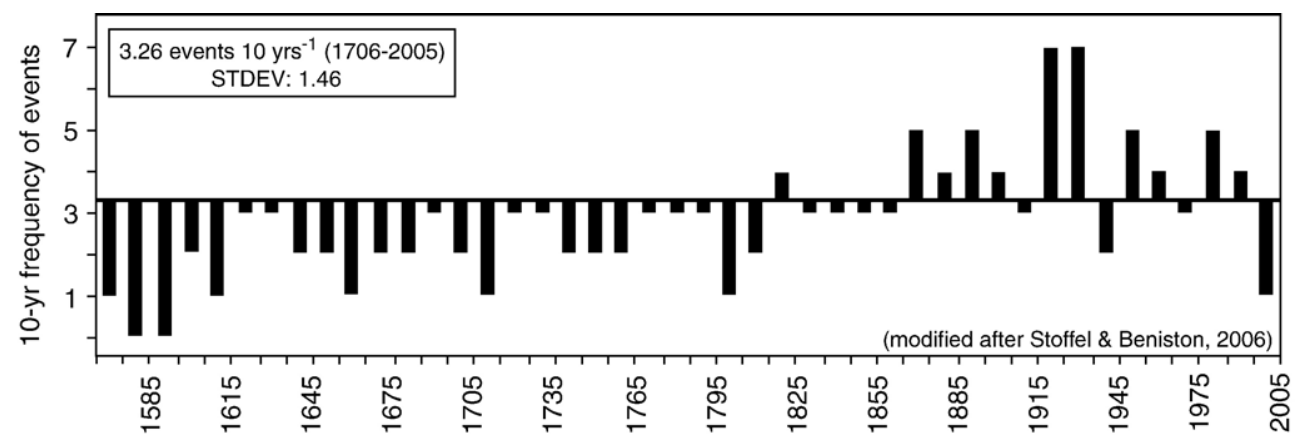

Fig. 6. Reconstructed 10-yr frequencies of debris-flow events between AD 1566 and 2005. Data are presented as variations from the mean decadal frequency of debris flows of the last $300 \mathrm{yr}$ (AD 1706-2005). 


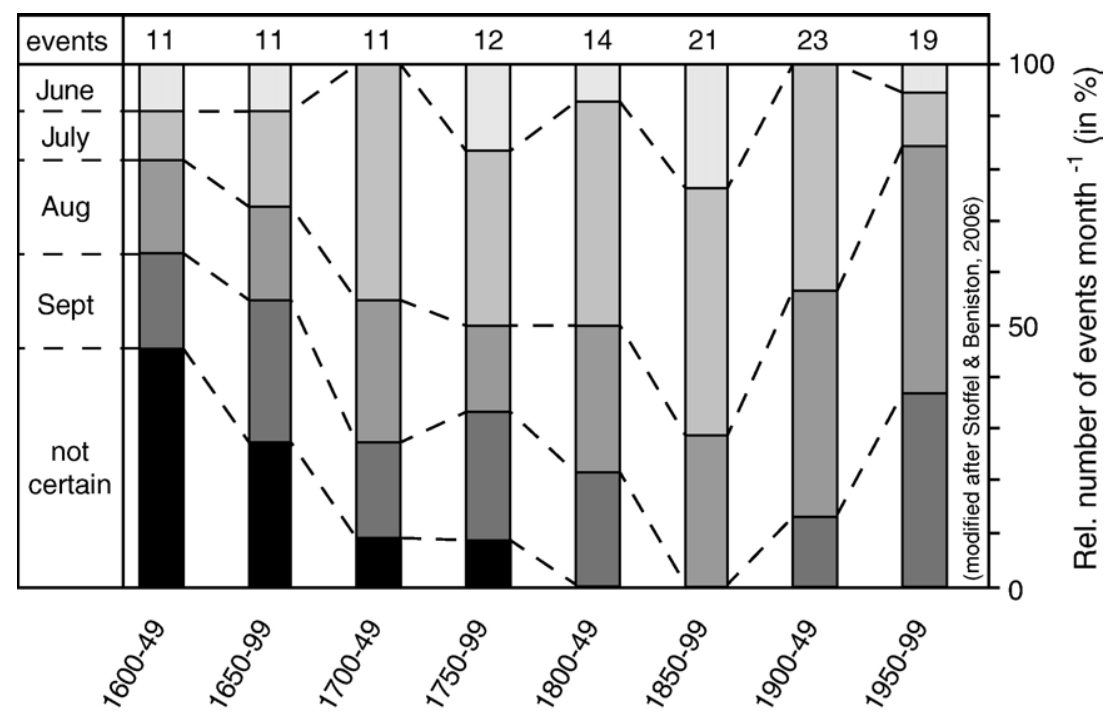

Fig. 7. Seasonality (JJAS) of past debris-flow activity as inferred from the intra-annual position of tangential rows of traumatic resin ducts (TRD) in the tree ring, archival data on flooding as well as meteorological data (1863-2005).

prior to 1900 . This is especially true for the period 1850 1899 , when more than $70 \%$ of the reconstructed debrisflow events took place in June and July, with none in September. In the 20th century, debris-flow activity clearly shifted towards August and September, with not a single event registered in June after AD 1962. Our reconstructions suggest that snowfall and frozen ground has inhibited debris entrainment from the source zone ( $>2600 \mathrm{~m}$ asl) during precipitation events between October and May.

\subsection{Dating debris-flow deposits and assessing spatial patterns of past events}

The analysis of injured, buried or tilted survivor trees in deposits allowed dating of 249 out of the 291 lobes identified on the intermediate cone (86\%). Attribution of GD to a specific lobe was most frequently achieved through the presence of tangential rows of traumatic resin ducts or reaction wood in trees located close to the snout of lobes. Due to the considerable size of boulders transported by individual surges, trees located in the flow path of debris flows were normally eliminated or died as a result of excessive burying. As a consequence, buried survivor trees were less readily available on the cone and abrupt growth suppression was only occasionally identified in the tree-ring records. Dating was not possible for 42 lobes $(14 \%)$, where trees were simply not present for analysis nor showed severe GD caused by past activity in their tree-ring record.
Fig. 8 represents the spatial distribution as well as the age of lobes deposited during 33 events since AD 1794. In Fig. 8, we only illustrate those events where $>600 \mathrm{~m}^{3}$ of material could be identified on the present-day surface. Results show that a majority of lobes that are visible on the present-day surface of the cone were deposited during the last 80 years. Although more than a third of all debris-flow events were reconstructed for the period 1570-1790, only six (2.4\%) of the 249 dated lobes could be attributed to events that occurred prior to 1794, with the oldest material dated on the cone to AD 1705. The pre-1794 deposits are illustrated in Fig. 8A as black surfaces.

Fig. 8A also illustrates dated material of selected 19th-century events with deposits identified on the present-day surface. In total, the analysis of GD in the tree-ring series allowed dating of 68 lobes $(27.3 \%)$ from the period 1794-1897. As with the features attributed to pre-1794 events, it should be noted that most of the lobes deposited by the 35 events reconstructed for the 19 th century have been overridden or eroded by more recent activity and that the equally small number of features does not imply that these events have been of smaller magnitude than more recent ones.

A total of 92 deposits (37\%) were dated for the period 1902-1934. For these early decades of the 20th century (Fig. 8B) dated material is largely restricted to the southwestern part of the cone and it seems that the 1922 event considerably remodeled the morphology of the cone around $1650 \mathrm{~m}$ asl. Even today, 26 lobes formed during this event remain visible on the surface. As a 

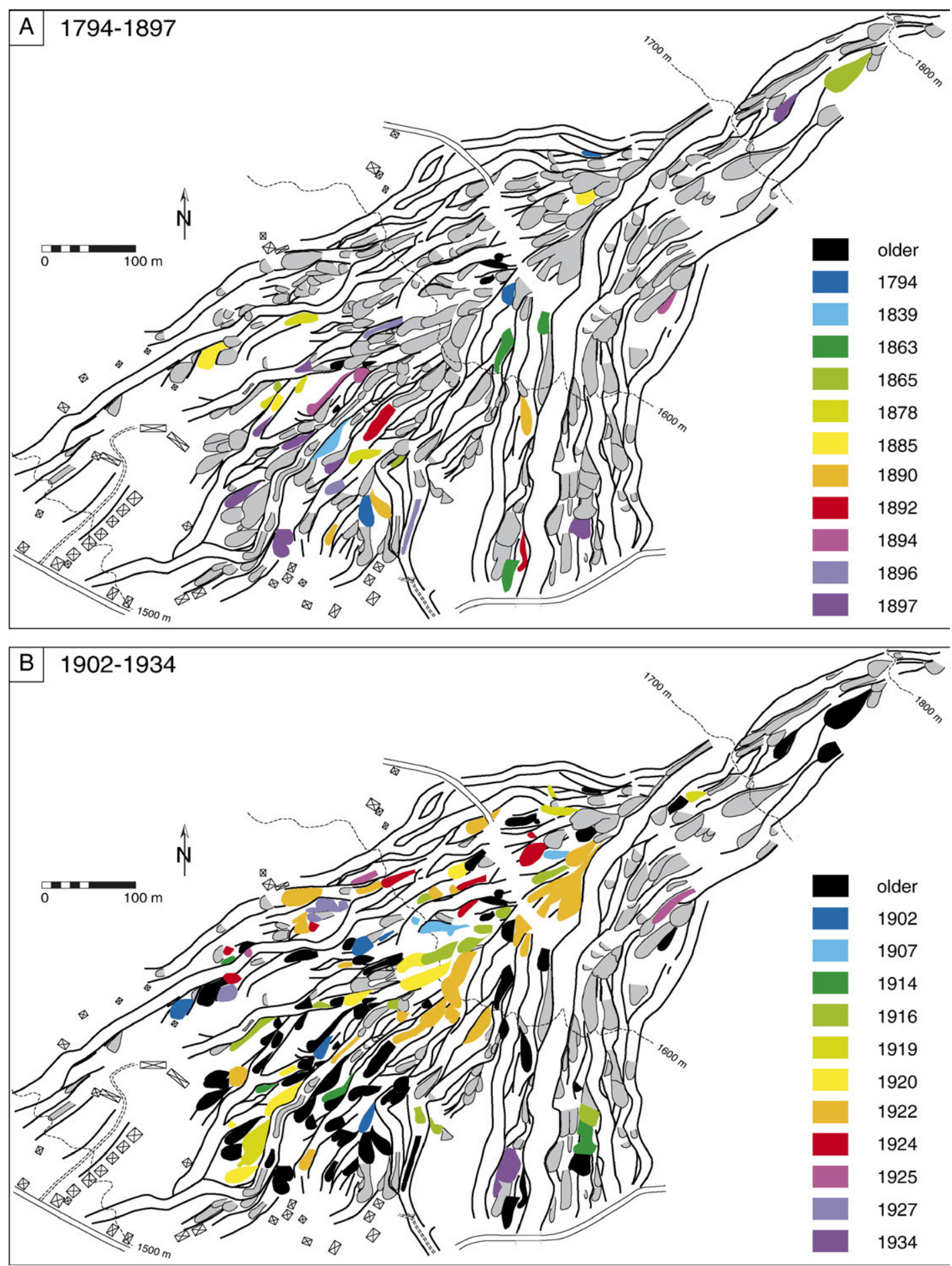

Fig. 8. Deposition of debris-flow material on the intermediate cone during past events. (A) Material deposited between 1794 and 1897 ; (B) Material deposited between 1902 and 1934. Only events that are associated with $>600 \mathrm{~m}^{3}$ on the present-day surface of the cone are indicated on the map. Deposits shown in black are dated, but are older than the time segment illustrated. Deposition of debris-flow material on the intermediate cone during past events. (C) Material deposited between 1935 and today. 


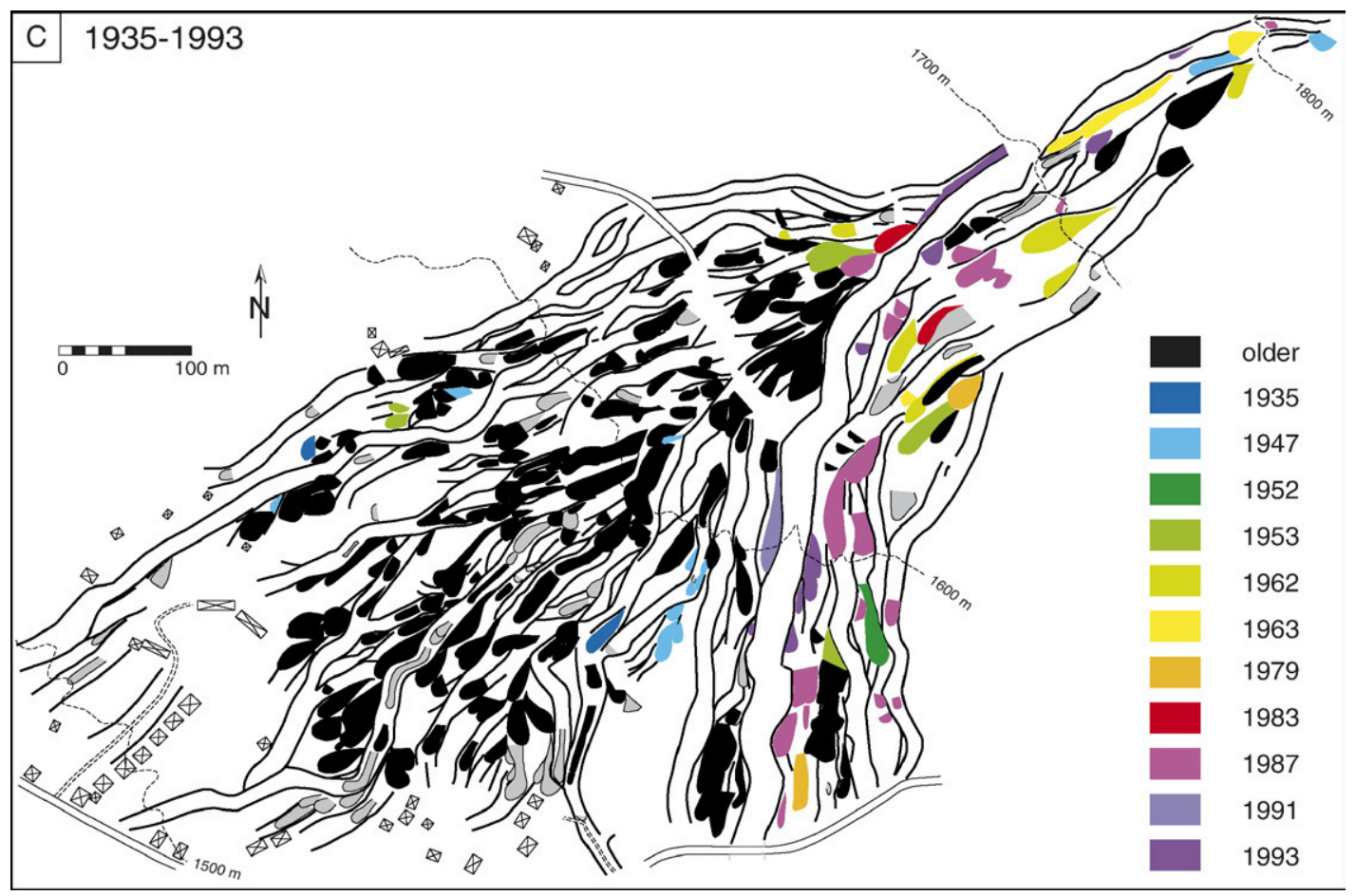

Fig. 8 (continued).

result of the large number of lobes and the considerable size of transported boulders (mean sizes of up to $3 \mathrm{~m}$ in diameter), the central part of the cone stopped being affected by debris flows after AD 1922 and surges were preferentially directed to the northwestern and eastern sectors of the cone.

Finally, 83 deposits (33.3\%) were attributed to events that have occurred during the last 70 years (1935-1993; Fig. 8C). It appears that, except for only a limited number of surges affecting the northwestern part of the study site (in 1935, 1947, 1953, and 1962), most debris flows affected the eastern segments of the cone. As a result of the deep incision of the current channel during the 1993 event, subsequent surges left no material on the intermediate cone, which is why the events of 1994 and 2002 are not illustrated in Fig. 8C.

\section{Discussion}

In the study we report here, increment cores extracted from 1102 living $L$. decidua, P. abies and P. cembra trees allowed reconstruction of 2263 growth disturbances (GD) belonging to 123 debris-flow events since $\mathrm{AD} 1566$. In addition, $86 \%$ of the deposits identified on the present-day surface of the intermediate cone of the Ritigraben torrent (Valais, Swiss Alps) were dated and spatial patterns of past activity identified.
On the basis of the evidence presented above, it is possible to characterize climatological as well as meteorological factors driving debris-flow activity in the casestudy area. Tree-ring based records of past debris-flow activity suggest that cool summers with frequent snowfalls at higher elevations (Pfister, 1999) regularly prevented the release of debris flows during most years between the 1570s and 1860s. The warming trend combined with greater precipitation totals in summer and autumn between 1864 and 1895 produced an increase in conditions favorable for the release of debris flows from the source zone. Enhanced debris-flow activity continued well into the 20th century and our reconstruction (Fig. 6) exhibits a clustering of events for the period 1916-1935, when warm-wet conditions prevailed during summer in the Swiss Alps (Pfister, 1999).

The reconstructed frequency is also in agreement with documented data on flooding events in Alpine rivers in Switzerland (see Lütschg-Lötscher, 1926; Röthlisberger, 1991), where a scarcity of flooding events is observed for most of the LIA and during the mid-20th century. However, it is worthwhile to note that floods in adjacent Alpine rivers became more frequent in the 1830s (Pfister, 1999), three decades before activity increased in the case-study area.

The timing of events also underwent changes over the period covered by the reconstruction. Based on the 
tree-ring record, we observe a shift in debris-flow activity from June and July to August and September over the 20th century, with not a single event registered in June after AD 1962. A comparison of reconstructed debris-flow events with archival data on flooding in adjacent rivers further indicates that convectional rainfall in summer (local thunderstorms) would have preferentially triggered debris flows from the 1860s until the 1980s. In contrast, cyclonic rainstorms affecting large parts of the Alps in late summer and early autumn are responsible for the debris-flow events of 1987, 1993 and 1994. While yet another cyclonic rainstorm caused considerable damage in rivers neighboring the casestudy site in October 2000, frozen ground and snowfalls inhibited excessive runoff and debris entrainment from the source zone of the Ritigraben located at $>2600 \mathrm{~m}$ asl (Bardou and Delaloye, 2004).

Our findings are also in agreement with data from Schmidli and Frei (2005), indicating a decrease in heavy summer rainfall and a slightly positive trend in heavy autumn precipitation intensities for the wider case-study area. Based on the IPCC A2 greenhouse-gas emissions scenario (see Nakićenović et al., 2000), a number of Regional Climate Models suggest a similar shift in the occurrence of heavy precipitation events in the Swiss Alps from summer to autumn (and spring) in a greenhouse climate by 2100 (Beniston, 2006). Spring and autumn temperatures are projected to remain $4-7{ }^{\circ} \mathrm{C}$ below current summer temperatures implying lower freezing levels in future springs and autumns as compared with current summers and therefore probably widespread buffering effects of snow on runoff and debris entrainment. Given that mean and extreme precipitation events are projected to occur less frequently in summer and that wet spells will become more common in spring and autumn, it is conceivable that debris flows will not necessarily occur as frequently in the future as they did in the past in the case-study area.

However, even if the frequency of summer events decreases in a future greenhouse climate, the magnitude and related impacts of future summer debris flows could be greater than currently. This is because warmer temperatures and higher precipitation intensities could result in greater runoff, an increase in the transport capacity of surges leading to a greater erosive potential of debris flows.

The release of debris flows and the ensuing magnitude of events not only depend on precipitation intensities and duration as well as on runoff, but also on sediment availability in the source zone and the channel. In the present case, an active rock glacier delivers sediments to the source zone and the main channel is continuously recharged with fallen rocks and material from former surges. Debris is, thus, readily available and easily entrained in the catchment and cannot therefore be considered a limiting factor under the current conditions. It is, however, conceivable that rock-glacier dynamics in the torrent's source zone or the soil structure and vegetation mantling the slopes in the neighborhood of the channel in the areas affected by erosion $(>1800 \mathrm{~m}$ asl) may have changed with time. Unlike Kotarba (1992) working in the Tatra Mountains who noted increased debris-flow activity due to major earthquakes and the subsequent delivery of material by rockfalls, we cannot identify an influence of the 1755 , 1855 and 1946 earthquakes (intensities $\geq$ VIII on the Medvedev-Sponheuer-Karnik (MSK) scale) on the reconstructed Ritigraben debris-flow frequency. Based on the above considerations, we conclude that debrisflow activity in the Ritigraben catchment over the last $\sim 300 \mathrm{yr}$ primarily depended on the presence of triggering meteorological events rather than on sediment supply. Prior to this period, the decreasing number of trees available for analysis may be partly responsible for an absence of events in the tree-ring based frequency.

The use of GD in tree rings for dating deposits on the intermediate cone introduces an additional tool to aid in our better understanding of the spatial patterns of past events and phases of aggradation or incision on the intermediate cone. Although our results clearly show that signs of pre-20th century events are recognizable in the tree-ring record of survivor trees, the material that caused the earlier incidences of GD was often completely overridden or eroded by more recent debris-flow activity. The overriding of deposits by subsequent events is likely to have been considerable at Ritigraben, since the volume of deposits identified on the presentday surface only accounts for $78,600 \mathrm{~m}^{3}$ as compared with the total volume of the intermediate cone estimated at $4.3 \times 10^{6} \mathrm{~m}^{3}$. We therefore believe that there must have been periods in the Holocene when debris entrainment from the source zone down the main channel was more abundant than during the last few centuries. Based on the geomorphic map and the dendrogeomorphological dating of events, we conclude that debrisflow activity of the 20th century was characterized by sediment accumulation on the cone and that the highmagnitude event in September $1993\left(60,000 \mathrm{~m}^{3}\right)$ is most likely to have been the only major incision event on the cone for at least the last century. We are thus aware that overriding and (partial) erosion of older deposits are important processes in the present-day accumulation of deposits on the cone and that, at best, a realistic image 
of spatial activity can only be provided for the 20th century.

The predominance of accumulation events on the intermediate cone should be taken into account in risk analysis, as the banks and levées of the current channel incised by the September 1993 event have already started to collapse in some places. As a result, future debris flows could overtop the channel above $1650 \mathrm{~m}$ asl, reactivate abandoned flow paths and deposit material on the eastern or southwestern parts of the cone, theoretically threatening buildings and public infrastructure.

\section{Conclusion}

Tree-ring based reconstructions of past debris-flow activity on a forested cone in the Valais Alps provide an unusually complete record of past events and deposition of material. Tree-ring based reconstructions of 123 debris flows since AD 1570 clearly show an increase in events during the wet summer months following the last LIA glacier maximum (1864-1895) and in the early decades of the 20th century. Thereafter, debris-flow activity gradually shifted to the late summer and early autumn, with a tendency for events to occur less frequently than in the past. We predict that, in a future greenhouse climate, debris-flow frequencies at the casestudy site could decrease, given that extreme precipitation events seem likely to occur less frequently in summer and that wet spells will become more common in spring or autumn. Further investigations using stratigraphic analysis of debris-flow material and the dating of organic layers of exposed sediments in the current channel could be used on the intermediate Ritigraben cone to reveal more fully its development during the Holocene and to identify substantial changes in climatic conditions and sediment supply.

\section{Acknowledgements}

The authors offer sincere thanks to Thierry Falco, Lukas Kuonen and Holger W. Gärtner for their assistance in the field and lab. We are also indebted to the Swiss Federal Office of Meteorology and Climatology (MeteoSwiss) for providing access to daily precipitation and temperature data. Michelle Bollschweiler is most warmly acknowledged for providing helpful comments on a former draft of the manuscript. We also acknowledge the anonymous reviewers for their insightful comments. This work has been undertaken partly in the context of the FP6 EU-project ENSEMBLES.

\section{References}

Bardou, E., Delaloye, R., 2004. Effects of ground freezing and snow avalanche deposits on debris flows in alpine environments. Nat. Hazards Earth Syst. Sci. 4, 519-530.

Beniston, M., 2006. August 2005 intense rainfall event in Switzerland: not necessarily an analog for strong convective events in a greenhouse climate. Geophys. Res. Lett. 33, L05701.

Blair, T.C., 1999. Sedimentology of the debris-flow dominated Warm Spring Canyon alluvial fan, Death Valley, California. Sedimentology 46, 941-957.

Blikra, L.H., Nemec, W., 1998. Postglacial colluvium in western Norway: depositional processes, facies and paleoclimatic record. Sedimentology 45, 909-945.

Blikra, L.H., Nemec, W., 2000. Postglacial colluvium in western Norway: depositional processes, facies and paleoclimatic record reply. Sedimentology 47, 1058-1065.

Bollschweiler, M., Stoffel, M., Ehmisch, M., Monbaron, M., in press. Reconstructing spatio-temporal patterns of debris-flow activity using dendrogeomorphological methods. Geomorphology. doi:10.1016/j.geomorph.2006.10.002.

Braam, R.R., Weiss, E.E.J., Burrough, P.A., 1987. Spatial and temporal analysis of mass movement using dendrochronology. Catena 14, 573-584.

Bradzil, R., Glaser, R., Pfister, C., Stangl, H., 2002. Floods in Europe a look into the past. Science Highlights Pages News, vol. 10.

Bräker, O.U., 2002. Measuring and data processing in tree-ring research - a methodological introduction. Dendrochronologia 20, 203-216.

Brazier, V., Whittington, G.W., Ballantyne, C.K., 1988. Holocene debris cone evolution in Glen Etive, Western Grampian Highlands, Scotland. Earth Surf. Process. Landf. 13, 525-531.

Brenning, A., Gruber, S., Hoelzle, M., 2005. Sampling and statistical analyses of BTS measurements. Permafr. Periglac. Process. 16, 383-393.

Caine, N., 1980. The rainfall intensity-duration control of shallow landslides and debris flows. Geogr. Ann. 62A, 23-27.

Christensen, J.H., Christensen, O.B., 2002. Severe summertime flooding in Europe. Nature 421, 802.

Christensen, J.H., Christensen, O.B., in press. A summary of the PRUDENCE model projections of changes in European climate by the end of this century. Clim. Change. doi:10.1007/s10584-0069210-7.

Cook, E.R., Kairiukstis, L.A., 1990. Methods of Dendrochronology Applications in the Environmental Sciences. Kluwer, London.

Fantucci, R., Sorriso-Valvo, M., 1999. Dendrogeomorphological analysis of a slope near Lago, Calabria (Italy). Geomorphology 30, 165-174.

Grove, J.M., 2004. Little Ice Ages: Ancient and Modern. Routledge, London.

Hupp, C.R., 1984. Geo-botanical evidence of late Quaternary mass wasting in block field areas of Virginia. Earth Surf. Processes Landf. 8, 439-450.

Jakob, M., Hungr, O., 2005. Debris-flow Hazards and Related Phenomena. Springer, Berlin.

Jonasson, C., 1993. Holocene debris-flow activity in northern Sweden. In: Frenzel, B., Matthews, J.A., Gläser, B. (Eds.), Solifluction and Climate Variations in the Holocene. Paläoklimaforschung, vol. 11. Gustav Fischer Verlag, Stuttgart, pp. 179-195.

Kotarba, A., 1992. High-energy geomorphic events in the Polish Tatra Mountains. Geogr. Ann. 74A, 123-131.

Labhart, T.P., 2004. Geologie der Schweiz, 6th edn. Ott Verlag, Thun. (in German). 
Lièvre, I., 2002. Détermination de la fréquence de laves torrentielles sur le torrent du Ritigraben (Valais, Suisse). MSc thesis, University of Fribourg, Fribourg, Switzerland (in French).

Lugon, R., Monbaron, M., 1998. Stabilité des terrains meubles en zone de pergélisol et changements climatiques. Deux études de cas en Valais: Le Ritigraben (Mattertal) et la moraine du Dolent (Val Ferret). vdf Hochschulverlag, Zürich (in French).

Lütschg-Lötscher, O., 1926. Über Niederschlag und Abfluss im Hochgebirge: Sonderdarstellung des Mattmarkgebietes: ein Beitrag zur Flussund Gletscherkunde der Schweiz. Schweiz. Wasserwirtschaftsverband, Zürich.

Matthews, J.A., Dahl, S.O., Berrisford, M.S., Nesje, A., Dresser, P.Q., Dumayne-Peaty, L., 1997. A preliminary history of Holocene colluvial (debris flow) activity, Leirdalen, Jotunheimen, Norway. J. Quat. Sci. 12, 117-129.

McAuliffe, J.R., Scuderi, L.A., McFadden, L.D., 2006. Tree-ring record of hillslope erosion and valley floor dynamics: landscape responses to climate variation during the last $400 \mathrm{yr}$ in the Colorado Plateau, northeastern Arizona. Glob. Planet. Change 50 (3-4), 184-201.

Milly, P.C.D., Wetherald, R.T., Dunne, K.A., Delworth, T.L., 2002. Increasing risk of great floods in a changing climate. Nature 415 , $514-517$.

Müller, H.N., 1980. Jahrringwachstum und Klimafaktoren: Beziehungen zwischen Jahrringwachstum von Nadelbaumarten und Klimafaktoren an verschiedenen Standorten im Gebiet des Simplonpasses (Wallis, Schweiz). Veröffentlichungen der Forstlichen BundesVersuchsanstalt Wien, Agrarverlag, Wien (in German).

Nakićenović, N., Alcamo, J., Davis, G., de Vries, B., Fenhann, J., Gaffin, S., Gregory, K., Grübler, A., Yong Jung, T., Kram, T., Lebre La Rovere, E., Michaelis, L., Mori, S., Morita, T., Pepper, W., Pitcher, H., Price, L., Riahi, K., Roehrl, A., Rogner, H.H., Sankovski, A., Schlesinger, M., Shukla, P., Smith, S., Swart, R., van Rooijen, S., Victor, N., Dadi, Z., 2000. IPCC Special Report on Emissions Scenarios. Cambridge University Press, Cambridge.

Perret, S., Stoffel, M., Kienholz, H., 2006. Spatial and temporal rockfall activity in a forest stand in the Swiss Prealps - a dendrogeomorphological case study. Geomorphology 74, 219-231.
Pfister, C., 1999. Wetternachhersage. 500 Jahre Klimavariationen und Naturkatastrophen. Paul Haupt, Bern (in German).

Rinntech, 2006. LINTAB — precision ring by ring. http://www.rinntech. com/Products/Lintab.htm.

Röthlisberger, G., 1991. Chronik der Unwetterschäden in der Schweiz. Berichte Forschungsanstalt Wald, Schnee und Landschaft, vol. 330, pp. 1-122.

Schmidli, J., Frei, C., 2005. Trends of heavy precipitation and wet and dry spells in Switzerland during the 20th century. Int. J. Climatol. $25,753-771$.

Schweingruber, F.H., 2001. Dendroökologische Holzanatomie. Paul Haupt, Bern (in German).

Sletten, K., Blikra, L.H., Ballantyne, C.K., Nesje, A., Dahl, S.O., 2003. Holocene debris flows recognized in a lacustrine sedimentary succession: sedimentology, chronostratigraphy and cause of triggering. Holocene 13, 907-920.

Stoffel, M., Beniston, M., 2006. On the incidence of debris flows from the early Little Ice Age to a future greenhouse climate: a case study from the Swiss Alps. Geophys. Res. Lett. 33, L16404.

Stoffel, M., Lièvre, I., Conus, D., Grichting, M.A., Raetzo, H., Gärtner, H.W., Monbaron, M., 2005a. 400 years of debris-flow activity and triggering weather conditions: Ritigraben, Valais, Switzerland. Arctic Antarc. Alp. Res. 37, 387-395.

Stoffel, M., Schneuwly, D., Bollschweiler, M., Lièvre, I., Delaloye, R., Myint, M., Monbaron, M., 2005b. Analyzing rockfall activity (1600-2002) in a protection forest — a case study using dendrogeomorphology. Geomorphology 68, 224-241.

Stoffel, M., Lièvre, I., Monbaron, M., Perret, S., 2005c. Seasonal timing of rockfall activity on a forested slope at Täschgufer (Valais, Swiss Alps) - a dendrochronological approach. Z. Geomorphol. 49, 89-106.

Stoffel, M., Bollschweiler, M., Hassler, G.R., 2006. Differentiating events on a cone influenced by debris-flow and snow avalanche activity - a dendrogeomorphological approach. Earth Surf. Process. Landf. 31, 1424-1437.

Zimmermann, M., Mani, P., Romang, H., 1997. Magnitude-frequency aspects of alpine debris flows. Eclogae Geol. Helv. 90, 415-420. 